\title{
Powder Preparation and Microstructure for Nano-Sized Metallic Iron Dispersed MgO Based Nanocomposites with Ferromagnetic Response
}

\author{
Tadachika NAKAYAMA, Yong-Ho CHOA, Tohru SEKINO and Koichi NIIHARA \\ The Institute of Scientific and Industrial Research, Osaka University, 8-1, Mihogaoka, Ibaraki-shi, Osaka 567-0047 \\ 強磁性を有するナノサイズ鉄を分散したマグネシア基ナノコンポジットの
粉末合成法と微細構造 \\ 中山忠親·左 容昊 $\cdot$ 関野 徹·新原晧一 \\ 大阪大学産業科学研究所, 567-0047 大阪府茨木市美穂ヶ丘 8-1
}

\begin{abstract}
MgO based nanocomposites including ferromagnetic iron particle dispersions, with a volume content $<40$ vol\%, were fabricated by a reduction/sintering of $\mathrm{MgO}$ and iron oxide powder mixtures. The oxide powder mixtures were prepared by solution chemical processes to obtain a suitable microstructure of ceramic/metal nanocomposites. Iron-nitrate as a source of metal dispersion was dissolved into alcohol and mixed with $\mathrm{MgO}$ powder. After calcination in air, the iron oxide in the powder mixture was reduced by hydrogen. Dense nanocomposites were obtained by pulse electric current sintering (PECS) process. Phase analysis of the synthesized powders as a function of calcination temperature and reduction process was carried out using a system for thermogravimetry and differential thermal analysis (TG-DTA), concurrently with X-ray diffraction (XRD) analysis. According to this preparation process, an MgO/Fe nanocomposite material with enhanced fracture toughness and ferromagnetic responses was successfully fabricated.
\end{abstract}

[Received November 10, 1999; Accepted June 21, 2000]

Key-words : Nanocomposite, Fe, MgO, PECS, Fracture toughness, Ferromagnetic

\section{Introduction}

Recent investigations have led to the development of ceramic/metal nanocomposites such as $\left.\mathrm{Al}_{2} \mathrm{O}_{3} / \mathrm{W},{ }^{1,}, 2\right) \mathrm{Al}_{2} \mathrm{O}_{3}$ / $\mathrm{Ni},{ }^{3), 4)} \mathrm{ZrO}_{2} / \mathrm{Ni}^{5)}$ and $\mathrm{MgO} / \mathrm{Ni}^{6}{ }^{6}$ The mechanical properties were improved due to the microstructural control associated with the nano-sized metal dispersion. Furthermore, Nidispersed $\mathrm{Al}_{2} \mathrm{O}_{3}$ nanocomposite exhibited both high strength and ferromagnetic properties. ${ }^{3), 4)}$ This implies that another combination of matrix and metal dispersion will also allow us to obtain nanocomposite materials with superior multiple properties.

Therefore, we have focused on the development of Fedispersed magnesia composites. Iron is superior to nickel in both mechanical and magnetic properties, and $\mathrm{MgO}$ ceramics show the desirable refractory with respect to molten metal and lower reactive materials than $\mathrm{Al}_{2} \mathrm{O}_{3}$ ceramics. In this composite, enhanced mechanical and magnetic properties, which have already been shown for the $\mathrm{Al}_{2} \mathrm{O}_{3} / \mathrm{Ni}^{3), 4)}$ and $\mathrm{MgO} / \mathrm{Ni}^{6}$ ) systems, are expected.

However, in order to develop such a material, optimization of the powder preparation and sintering process and an understanding of the role of the nano-sized dispersions are required. Recently, pulse electrical current sintering process (PECS) has gained much interest as a new process similar to hot-pressing (HP), because the pressure is applied during heating. PECS enables to sinter at considerably higher heating rates, thereby giving the refinement of the second phase metal particle by skipping the coarsening region at low temperatures. ${ }^{7)-9)}$

To fabricate the fine Fe-particle dispersed $\mathrm{MgO}$ composites, both reduction and PECS process was applied to $\mathrm{MgO}$ and iron oxide mixtures prepared by a solution chemically route. The purpose of the present work is to investigate the powder preparation process and the relationship between the microstructure and mechanical properties of $\mathrm{MgO} / \mathrm{Fe}$ nanocomposites and to evaluate the magnetic properties which are closely relate to the microstructure.

\section{Experimental procedure}

The solution chemistry route was selected to obtain the powder mixtures used for the composites. High-purity iron nitrate $\left(\mathrm{Fe}\left(\mathrm{NO}_{3}\right)_{3} \cdot 9 \mathrm{H}_{2} \mathrm{O}, 99.9 \%\right.$; Wako Pure Chemical Industries, Ltd.) was used as a source material for metal dispersion. Weighted nitrate corresponding to 0 to $40 \mathrm{vol} \%$ of metal in the final specimens was dissolved in alcohol. Subsequently, $\mathrm{MgO}$ powder with an average particle size $\approx 100$ $\mathrm{nm}$ (Ube Material Industries, Ltd.) was mixed with the nitrate solution and ball-milled for $24 \mathrm{~h}$. After drying, the mixtures were ball-milled for $12 \mathrm{~h}$ and calcined at $673 \mathrm{~K}$ for $2 \mathrm{~h}$ in air to obtain $\mathrm{MgO}$ /iron oxide mixed powders. The obtained oxide powder mixtures were reduced to $\mathrm{MgO} / \mathrm{Fe}$ under hydrogen gas flow at $1373 \mathrm{~K}$ for $1 \mathrm{~h}$. The pulse electric current sintering (SPS 3.20 MK-IV; Sumitomo Coal Mining Co., Ltd.) with an applied uni-axial pressure of $100 \mathrm{MPa}$ was accomplished at $1473 \mathrm{~K}$ for $5 \mathrm{~min}$ under an Ar-gas atmosphere and a fixed heating rate of $200 \mathrm{~K} / \mathrm{min}$.

Simultaneous thermogravimetry and differential thermal analysis (TG-DTA) of the $\mathrm{MgO}$ /iron nitrate mixtures were performed using a Shimadzu DTG-50 in air at a heating rate of $10 \mathrm{~K} / \mathrm{min}$ up to $673 \mathrm{~K}$. All sintered samples were cut and polished by diamond pastes to get the mirror surfaces. The resultant phases were characterized by X-ray diffraction (XRD). Scanning electron microscopy (SEM) and transmission electron microscopy (TEM) were used to study the composite powder morphology and the microstructure of sintered materials. Density was measured by the Archimedes method using toluene. Hardness $\left(H_{\mathrm{V}}\right)$ was evaluated by Vickers indentation using a load of $98 \mathrm{~N}$ for 15 $\mathrm{s}$ in air. Fracture toughness $\left(K_{\mathrm{IC}}\right)$ at room temperature was determined by the indentation fracture (IF) method. ${ }^{10)} K_{\text {IC }}$ values were calculated using the empirical equation proposed by Niihara et al. ${ }^{10)}$ for a median crack. Magnetization curve of each composite was measured using a SQUID magnetometer with an applied magnetic field up to \pm 15000 gauss. 


\section{Results and discussion}

3.1 Phase composition of powders and sintered composites

TG-DTA curves of the $\mathrm{MgO} / \mathrm{Fe}$-nitrate mixture $(\mathrm{MgO} /$ $20 \mathrm{vol} \% \mathrm{Fe}$ ) shown in Fig. 1 demonstrate that almost all of the weight loss occurs below $673 \mathrm{~K}$ due to loss of water of hydration and nitrate decomposition. After heating at $673 \mathrm{~K}$ for $1 \mathrm{~h}$, the weight loss was complete. From these results, we fixed calcination temperatures to be $673 \mathrm{~K}$ for $\mathrm{MgO} / \mathrm{Fe}$ nitrate mixtures.

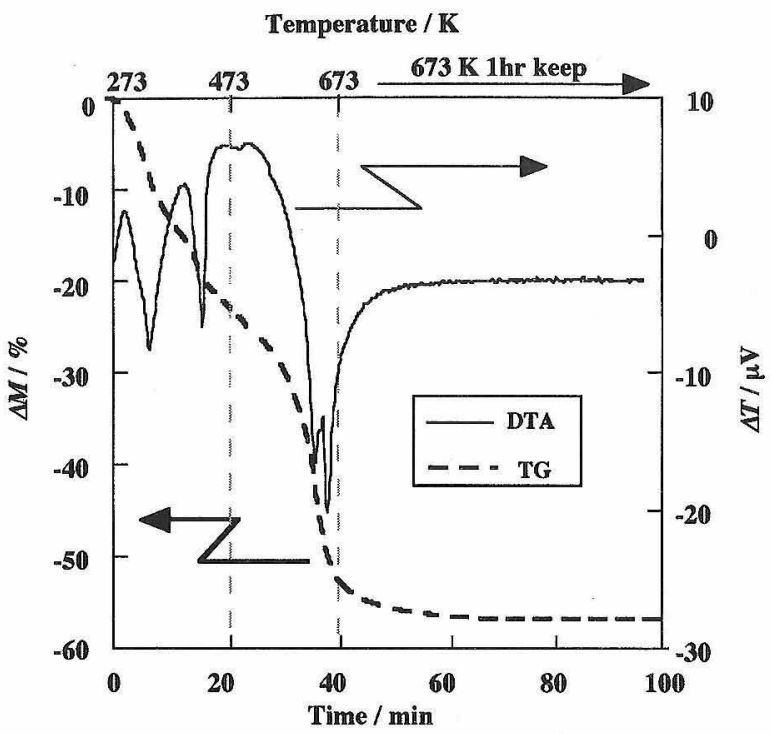

Fig. 1. Thermogravimetry and differential thermal analysis (TG-DTA) curves for the $\mathrm{MgO} / \mathrm{Fe}$-nitrate mixture (heating at 10 $\mathrm{K} / \mathrm{min}$ up to $673 \mathrm{~K}$ ).

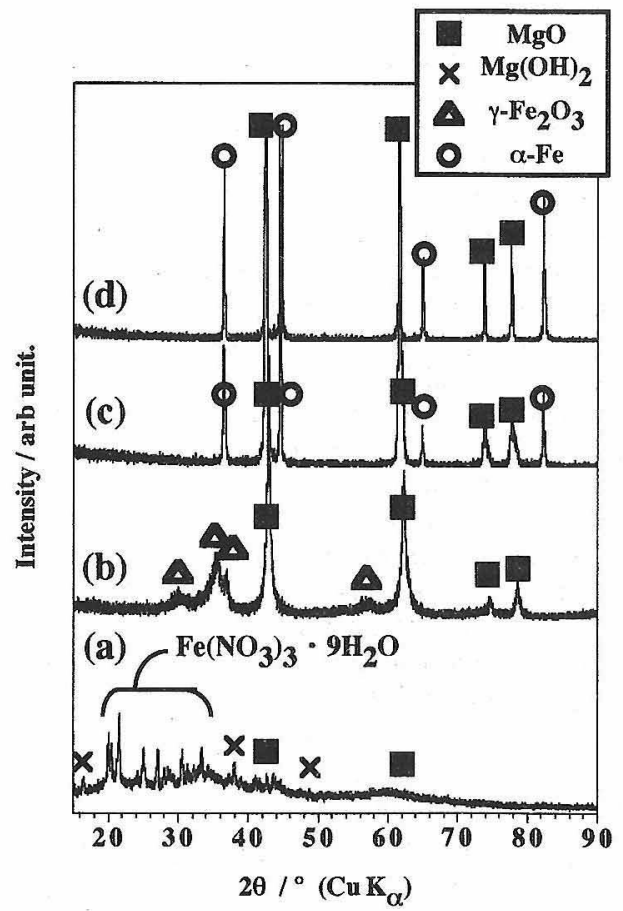

Fig. 2. XRD patterns for the starting mixture prepared by solution chemistry route for the mixture of $\mathrm{MgO}$ and $\mathrm{Fe}\left(\mathrm{NO}_{3}\right)_{3} \cdot 9 \mathrm{H}_{2} \mathrm{O}$

(a) after drying, (b) after calcination, (c) after reduction and (d) after sintering.
The XRD patterns for the $\mathrm{MgO} / 20$ vol\% Fe composite prepared by calcining, reducing, and sintering processes are shown in Fig. 2. The XRD pattern after drying (Fig. 2(a)) contains the characteristic peaks for $\mathrm{MgO}, \mathrm{Mg}(\mathrm{OH})_{2}$ and $\mathrm{Fe}\left(\mathrm{NO}_{3}\right)_{3} \cdot 9 \mathrm{H}_{2} \mathrm{O}$. After calcination at $673 \mathrm{~K}$, the Fe-nitrate forms $\gamma$ - $\mathrm{Fe}_{2} \mathrm{O}_{3}$ (Fig. 2(b)). No reaction phase such as Fespinel was observed in this experiment. After reduction at $1373 \mathrm{~K}, \gamma-\mathrm{Fe}_{2} \mathrm{O}_{3}$ turned to metallic iron, however no other reaction phases are observed (Fig. $2(\mathrm{c})$ ). In addition, no reduction of the $\mathrm{MgO}$ matrix was observed in this experiment. Even after sintering, the XRD pattern reveals metallic iron and $\mathrm{MgO}$ as the only crystalline constituents (Fig. 2 (d)).

TEM observation of the calcined powder mixtures revealed that the primary particle size of $\gamma-\mathrm{Fe}_{2} \mathrm{O}_{3}$ was approximately $20-30 \mathrm{~nm}$ for the $\mathrm{MgO} / 20 \mathrm{vol} \% \mathrm{Fe}$ mixture. The produced $\gamma-\mathrm{Fe}_{2} \mathrm{O}_{3}$ particles mainly existed around $\mathrm{MgO}$ particles. The size distribution of iron metal has been initial stage not shown hydrogen reduction at $1373 \mathrm{~K}$ for $1 \mathrm{~h}$ as shown in Fig. 3(b).

A surprising results is that the particle size of $\mathrm{MgO}$ with of $100 \mathrm{~nm}$ (see also Fig. 3(a)) decreases down to several ten $\mathrm{nm}$ for the composite powders after hydrogen reduction at $1373 \mathrm{~K}$ for $1 \mathrm{~h}$, while, after wet ball-milling and drying of only $\mathrm{MgO}$ powder with $\mathrm{BuOH}$, the particle size of $\mathrm{MgO}$ powder was not changed under the same milling conditions. The reason for these observations may be found in the hydration (the formation of $\mathrm{Mg}(\mathrm{OH})_{2}$ ) of the $\mathrm{MgO}$ powder
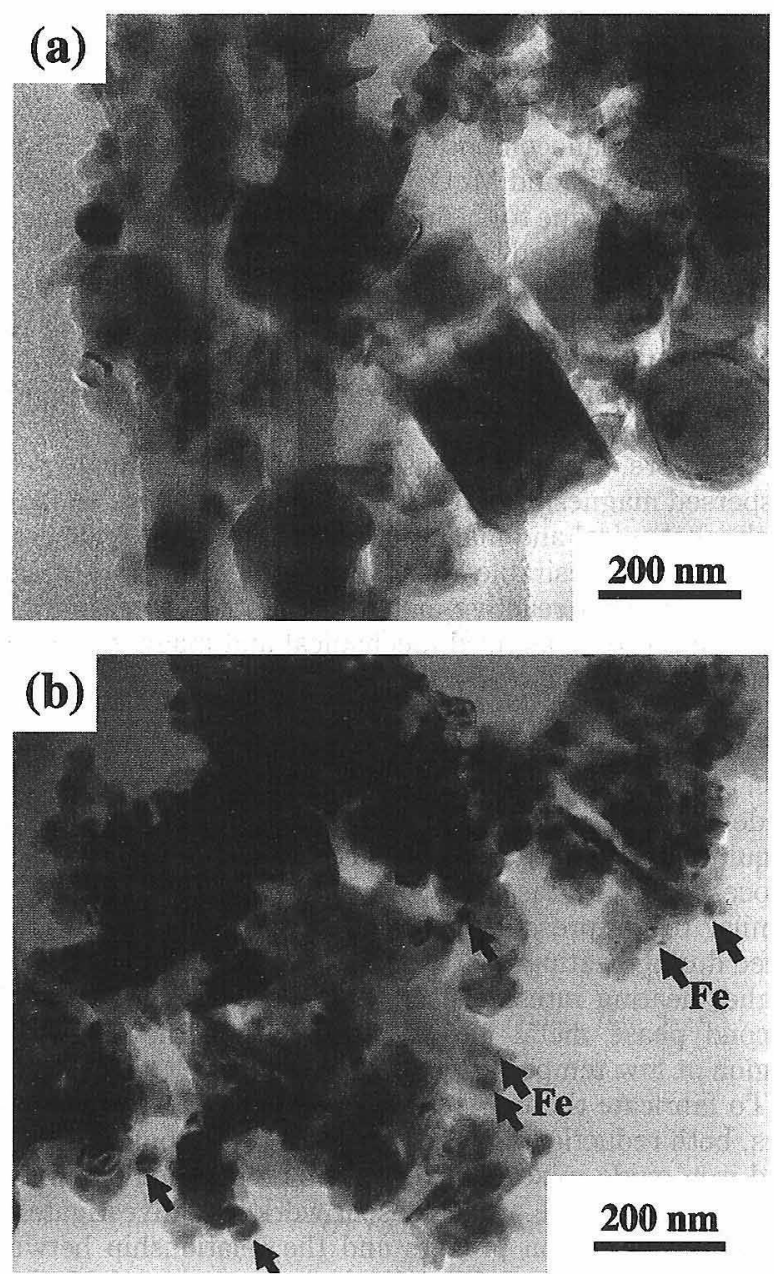

Fig. 3. TEM micrographs of the (a) as-received $\mathrm{MgO}$ powder and (b) $\mathrm{MgO} / 20$ vol\% Fe nanocomposite powder reduced at $1373 \mathrm{~K}$. 
via the water from nitrate. In the presence of $\mathrm{MgO}$, the hydration of $\mathrm{MgO}$ is (relatively easy) formed, ${ }^{11)}$ specially the hydration will be enhanced during the wet-milling process according to Eq. (2).

Thus, a fracture of the $\mathrm{MgO}$ powder reacted with water to nitrate, and sequentially the particle size of $\mathrm{MgO}$ is decreased when $\mathrm{Mg}(\mathrm{OH})_{2}$ again decomposes to $\mathrm{MgO}$ by calcination at $673 \mathrm{~K}$ (Eq. (3)).

$$
\mathrm{Fe}\left(\mathrm{NO}_{3}\right)_{3} \cdot 9 \mathrm{H}_{2} \mathrm{O}+\text { alcohol } \longrightarrow
$$$$
\mathrm{Fe}\left(\mathrm{NO}_{3}\right)_{3}+9 \mathrm{H}_{2} \mathrm{O}+\text { alcohol (in alcohol) }
$$$$
\mathrm{MgO}(\mathrm{s})+\mathrm{H}_{2} \mathrm{O}(\mathrm{l}) \longrightarrow
$$$$
\mathrm{Mg}(\mathrm{OH})_{2}(\mathrm{~s}) \text { (during the wet-milling) }
$$

$$
\mathrm{Mg}(\mathrm{OH})_{2} \longrightarrow
$$$$
\mathrm{MgO}+\mathrm{H}_{2} \mathrm{O}(\mathrm{g}) \text { (during the calcination) }
$$

This reaction mechanism would explain, the presence of $\mathrm{Mg}(\mathrm{OH})_{2}$ peaks in the XRD analysis of the dried powder mixture before calcination, as shown Fig. 2.

Sintering was performed under an Ar-gas atmosphere at $1473 \mathrm{~K}$ using PECS method. XRD analysis revealed that the specimens sintered by the fabrication sequence were only composed of $\mathrm{MgO}$ and $\mathrm{Fe}$ without any additional reaction phases. Figure 4 shows the TEM micrograph of the $\mathrm{MgO}$ / $20 \mathrm{vol} \% \mathrm{Fe}$ composite. The densely sintered $\mathrm{MgO} / \mathrm{Fe}$ nanocomposite shows a bimodal distribution of the particle size of metallic Fe dispersions, that is, 10 to $30 \mathrm{~nm}$ for intragranular dispersions and 300-600 nm for intergranular dispersions at grain boundaries and triple junctions. The size of intergranular particles increased with increasing iron content (from $50-150 \mathrm{~nm}$ for $\mathrm{MgO} / 5$ vol\% $\mathrm{Fe}$ to $300-600$ $\mathrm{nm}$ for $\mathrm{MgO} / 20 \mathrm{vol} \% \mathrm{Fe}$ ). From these results it is clearly understood that intergranular Fe particles were grown with increasing sintering temperature and increasing volume fraction of $\mathrm{Fe}$. It is assumed that this feature was due to migration and coalescence of metallic $\mathrm{Fe}$ particles, owing to their higher mobility as a second phase in the $\mathrm{MgO} / \mathrm{Fe}$ system, as compared to the $\mathrm{MgO}$ grain boundaries. As a result, metallic $\mathrm{Fe}$ particles, which are located at $\mathrm{MgO}$ grainboundaries or triple junction, dragged along during the movement of $\mathrm{MgO}$ grain boundaries, and the coalescence of metallic Fe particles was occurred. It is, therefore, reported above that iron particulate dispersion can inhibit the matrix grain growth similar to $\mathrm{SiC}^{12}$ and $\mathrm{Ni}^{\text {i6) }}$ dispersions in $\mathrm{MgO}$.

$\mathrm{MgO}$ matrix grain size of the $\mathrm{MgO} / 20$ vol\% Fe composite sintered at $1473 \mathrm{~K}$ was approximately $1.3 \mu \mathrm{m}$ and increased to be around $2.5 \mu \mathrm{m}$ when the specimen was sintered at $1673 \mathrm{~K}$. In comparison, the corresponding grain size of the pure $\mathrm{MgO}$ monolith was about $4.2 \mu \mathrm{m}$ after sintering at 1673 $\mathrm{K}$. Coalescence of metallic $\mathrm{Fe}$ particles consequently increases the drag force required for the movement of $\mathrm{MgO}$

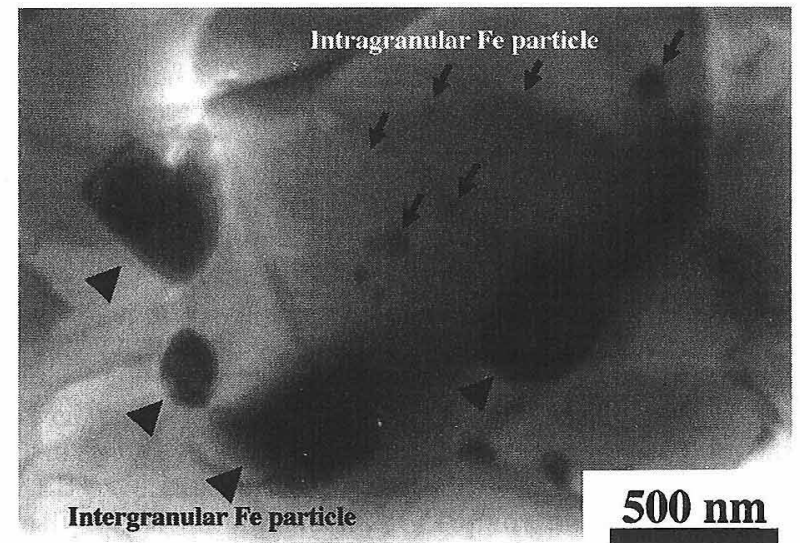

Fig. 4. TEM micrograph of $\mathrm{MgO} / 20$ vol\% Fe composite PECSed at $1473 \mathrm{~K}$ for $5 \mathrm{~min}$. grain boundary, which, as a result, inhibits the $\mathrm{MgO}$ grain growth.

\subsection{Mechanical properties}

Figure 5 shows the effect of iron content on Vickers hardness $\left(H_{\mathrm{V}}\right)$ and fracture toughness $\left(K_{\mathrm{IC}}\right)$ for $\mathrm{MgO} / \mathrm{Fe}$ composites sintered at $1473 \mathrm{~K}$. The Vickers hardness decreased with increasing volume fraction of iron. On the other hand, the fracture toughness of $1.1 \mathrm{MPa} \cdot \mathrm{m}^{1 / 2}$ for the $\mathrm{MgO}$ monolith increased to $2.35 \mathrm{MPa} \cdot \mathrm{m}^{1 / 2}$ for the $\mathrm{MgO} / 40 \mathrm{vol} \%$ Fe composite. The toughening mechanism was considered to be crack deflection and particle bridging by ductile $\mathrm{Fe}$ particles. In Fig. 6, the SEM image of the crack propagation in the $\mathrm{MgO} / 20$ vol\% Fe composite is shown. It was clearly found that the crack was deflected by Fe particles and partly bridging by ductile metallic Fe particles.

3.3 Magnetic properties

For the $\mathrm{MgO} / 20 \mathrm{vol} \% \mathrm{Fe}$ composite system, a hysteresis loop of the $I-H$ curve was obtained by SQUID magnetometer measured at $300 \mathrm{~K}$ (Fig. 7). This figure clearly showing the ferromagnetism of metallic Fe particles disspersed in the $\mathrm{MgO}$ matrix. The saturation magnetization ( $I s)$ of the composite is estimated by an Arrott plot. Is is found to be 187 emu/iron gram, which is close to the value of pure iron at room temperature, $217.2 \mathrm{emu} / \mathrm{gram}$. The coercive force $\left(H_{c}\right)$ is 55 gauss, which is approximately two orders of magnitude larger than that of pure iron metal (less than 1.0 gauss $\left.{ }^{13)}\right) . H_{\mathrm{c}}$ is well known to be strongly dependent on the particle size and dislocation density.4),14) When the particle size of a magnetic material decreases, its magnetic structure varies from a multi domain state to a single domain state, in

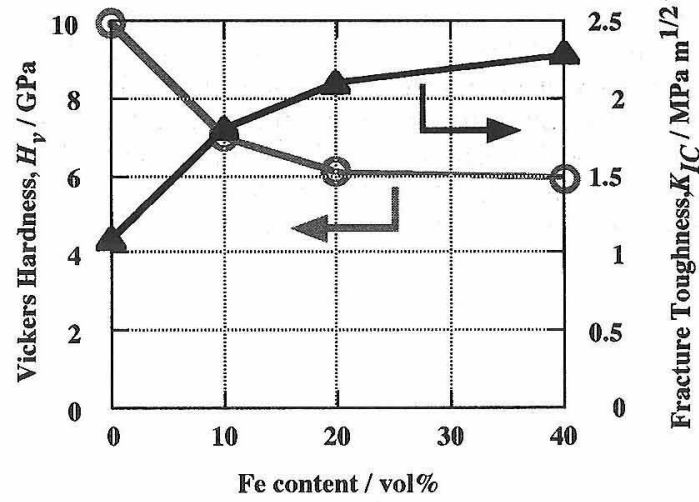

Fig. 5. Variation of the Vickers hardness, $H_{\mathrm{V}}$ and fracture toughness, $K_{\text {IC }}$ with the $\mathrm{Fe}$ content for the $\mathrm{MgO} / \mathrm{Fe}$ composites.

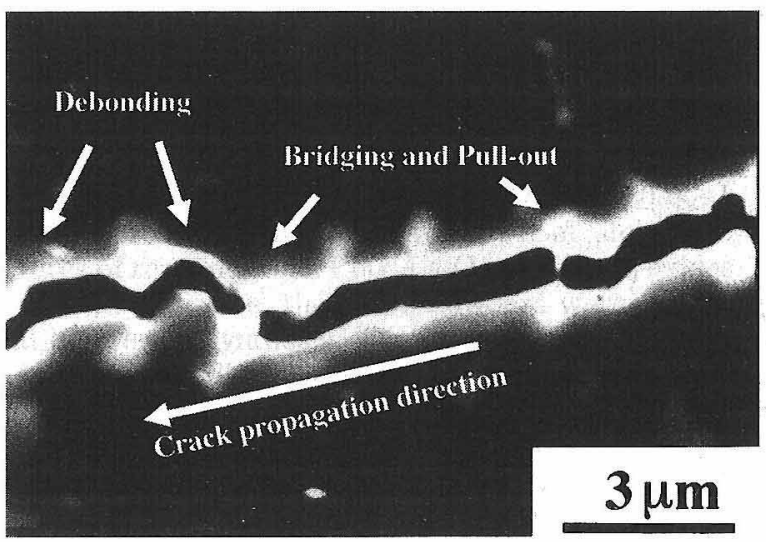

Fig. 6. SEM micrograph of typical crack propagation in $\mathrm{MgO} / 20$ vol\% Fe composite. 


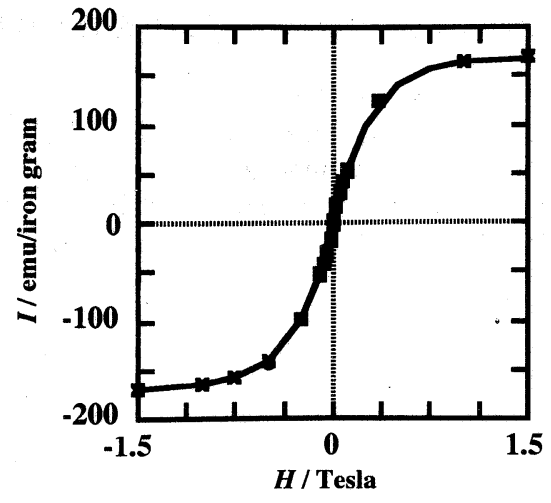

Fig. 7. Magnetization curve for $\mathrm{MgO} / 20 \mathrm{vol} \% \mathrm{Fe}$ composite measured at $300 \mathrm{~K}$.

order to reduce the total energy of the system; hence a high $H_{\mathrm{c}}$ is recorded. ${ }^{14)}$ The extremely high value of $H_{\mathrm{c}}$ was reported for particle size in the range of several ten $\mathrm{nm}$, which corresponds to the magnetic single domain structure. In this composite, the size of the intragranular iron particles lies in the few ten nm range (see Fig. 4), therefore, it is cogitabled that the present $\mathrm{Fe}$ particle dispersion has a single domain structure.

\section{Conclusions}

$\mathrm{MgO}$ based nanocomposites with ferromagnetic iron par ticle dispersions were successfully fabricated by reduction and $\mathrm{PECS}$ process of $\mathrm{MgO} / \gamma-\mathrm{Fe}_{2} \mathrm{O}_{3}$ composite powders prepared by a solution chemical route. The typical microstructure of the $\mathrm{MgO} / \mathrm{Fe}$ composites showed that the dispersed $\mathrm{Fe}$ particles were composed of intragranular $\mathrm{Fe}$ nano-sized particles of a few ten $\mathrm{nm}$ and intergranular Fe particles of several hundred $\mathrm{nm}$ in size. This distinguished microstructure was due to migration and coalescence of metallic $\mathrm{Fe}$ particles during the sintering process. After metallic Fe par- ticles were coalesced, the drag force of Fe particles acting on the $\mathrm{MgO}$ grain boundaries was enhanced and the growth of $\mathrm{MgO}$ grain was inhibited. The observed fracture toughness increased with increasing volume fraction of iron particles. The toughness increase was due to the crack deflection and plastic deformation of the ductile $\mathrm{Fe}$ particles, as revealed by SEM imaging. Furthermore, $\mathrm{MgO} / \mathrm{Fe}$ composites showed an enhanced coercive force as compared to pure $\mathrm{Fe}$ materials, due to the presence of intragranular nano-sized iron particles.

\section{Refernces}

1) T. Sekino and K. Niihara, Nanostruct. Mater., 6, 663-66 (1995).

2) T. Sekino and K. Niihara, J. Mater. Sci., 32, 1943-49 (1997).

3) T. Sekino, T. Nakajima and K. Niihara, Mater. Lett., 29, 165-69 (1996).

4) T. Sekino, T. Nakajima, S. Ueda and K. Niihara, J. Am. Ceram. Soc., 80, 1139-48 (1997)

5) H. Kondo, T. Sekino, Y.-H. Choa and K. Niihara, Key Eng. Mater., 161-163, 419-22 (1999).

6) Y.-H. Choa, H. Hayashi, T. Sekino and K. Niihara, Key Eng. Mater., 161-163, 493-96 (1999).

7) A. Kamiya, J. Mater. Sci. Lett., 7, 49-51 (1998).

8) I. Kondoh, T. Tanaka and N. Tamari, J. Ceram. Soc. Japan, 102, 505-07 (1994) [in Japanese].

9) M. Omori and T. Hirai, New Ceramics, 7, 4-8 (1994) [in Japanese].

10) K. Niihara, R. Morena and D. P. H. Hasselman, J. Mater. Sci. Lett., 1, 13-16 (1982).

11) T. Seta, Proceedings of an International Symposium held at the Massachusetts Institute of Technology in Cambridge, Massachusetts on June 13-16, 1983, Ed. by W. D. Kingery, Am. Ceram. Soc., Westerville (1984) pp. 541-46.

12) Y.-H. Choa, H. Kawaoka, T. Sekino and K. Niihara, Key Eng. Mater., 132-133, 2009-12 (1997).

13) H. Kaneko and M. Honma, "Zisei Zairyo," Japan Inst. Metals (1977) p. 143.

14) R. Kamel and A. Reffat, Solid State Commun., 8, 821-23 (1970). 